HORTSCIENCE 26(7):908-910. 1991.

\title{
Plant Regeneration from Cotyledons of Cucumis melo 'Topmark'
}

\author{
Paula P. Chee \\ Molecular Biology Research, The Upjohn Company, 301 Henrietta \\ Street, Kalamazoo, MI 49007 \\ Additional index words. muskmelon, plant tissue culture, organogenesis, cantaloupe
}

\begin{abstract}
A procedure for the regeneration of muskmelon (Cucumis melo L.) CV. Topmark via shoot organogenesis from cotyledon explants is described. The best induction medium for a morphogenic response was MS salts and vitamins medium with BA at $1.0 \mathrm{mg} \cdot \mathrm{liter}^{-1}$. Further vegetative bud development was completed by transferring organogenic tissue to MS medium containing BA at $0.05 \mathrm{mg} \cdot \mathrm{liter}^{-1}$ The shoots were rooted in MS medium containing NAA at $0.01 \mathrm{mg} \cdot$ liter $^{-1}$. Morphologically normal plantlets were obtained. Chemical abbreviations used: 6-benzylaminopurine (BA); indoleacetic acid (IAA); naphthaleneacetic acid (NAA).
\end{abstract}

The literature descriptions of tissue culture methods applied to muskmelon are few. Blackmon and Reynolds (1982) first documented the development of adventitious shoots from cotyledon and primary leaf explants. Moreno et al. (1985), Kathal et al. (1988), Dirks and Buggenum (1989), and Niedz et al. (1989) also reported that muskmelon plants could be regenerated from cotyledon and leaf explants. Oridate and Oosawa (1986) observed plantlet regeneration from suspension culture-derived somatic embryos. These procedures are not necessarily applicable to other cultivars (D. Gonsalves, personal communication) because of the genotype specificity of the methods. This reort describes a technique for the regeneration of whole muskmelon plants from cotyledon explants $C$. melo 'Topmark' through shoot organogenesis. The same procedure was also applicable to 'Perlita' muskmelon, another netted cultivar.

Seeds of 'Topmark' (Asgrow Seed Co., Kalamazoo, Mich.) were soaked in tap water

Received for publication 5 June 1990. The cost of publishing this paper was defrayed in part by the payment of page charges. Under postal regulations, this paper therefore must be hereby marked advertisement solely to indicate this fact. for $\approx 15 \mathrm{~min}$. Seed coats were removed manually. De-coated seeds were surface sterilized for $10 \mathrm{~min}$ with $10 \%(\mathrm{v} / \mathrm{v})$ solution of commercial bleach containing a trace amount of Tween-20 (Sigma, St. Louis) spreader and then rinsed three times with sterilized distilled water. Sterilized decoated seeds were germinated on MS medium (Murashige and Skoog, 1962) containing $0.1 \%$ activated charcoal (optional) and at $26 \mathrm{C}$ with a $16-\mathrm{h}$ photoperiod under standard cool-white fluorescent lamp (4 klx). Unless otherwise stated, all media were supplemented with $3 \%$ sucrose and solidified with $0.6 \%$ Phytagar (Gibco). The $\mathrm{pH}$ of all media was adjusted to 5.8 before they were autoclave at $121 \mathrm{C}$ for $20 \mathrm{~min}$.

Cotyledons from 9- to 10-day-old seedlings grown in vitro were cut longitudinally into halves and placed on induction medium with the abaxial side down. Induction medium was composed of MS medium (Murashige and Skoog, 1962) supplemented with either BA $\left(0.0,0.5,0.75,1.0 \mathrm{mg} \cdot\right.$ liter $\left.^{-1}\right)$ or IAA at $1.5 \mathrm{mg} \cdot$ liter $^{-1}$ and kinetin at 6.0 mg.liter ${ }^{-1}$ (I-K medium; Moreno et al., 1985). Explants were incubated at $26 \mathrm{C}$ under diffuse cool-white fluorescent lamps (4 klx). One hundred explants were evaluated per 
Table 1. Organogenic response (bud formation) of 'Topmark' muskmelon cotyledon explants on MS medium supplemented with growth regulators ${ }^{z}$.

\begin{tabular}{lc}
\hline \hline $\begin{array}{l}\text { Growth regulator } \\
\left(\mathrm{mg} \cdot \text { liter }^{-1}\right)\end{array}$ & $\begin{array}{c}\text { Explants producing } \\
\text { organogenic tissues } \\
(\%)\end{array}$ \\
\hline BA $(1.0)$ & 80 \\
$(0.75)$ & 60 \\
$(0.5)$ & 4 \\
IAA $(1.5)+\mathrm{KN}(6.0)$ & 20 \\
Control $(0)$ & 0 \\
LSD $(5 \%)$ & 10 \\
CV & 12 \\
\hline
\end{tabular}

${ }^{2}$ Data represent the mean of two experiments $(n=200)$. The response is significantly different among treatments, $\chi^{2}$ value is $450.5(P<0.001)$.

Table 2. Rooting response of 'Topmark' muskmelon shoots on MS medium supplemented with various levels of NAA .

\begin{tabular}{lccc}
\hline \hline & \multicolumn{3}{c}{$\begin{array}{c}\text { Rooting response of shoots } \\
\text { (no./total) }\end{array}$} \\
\cline { 2 - 3 } \multicolumn{3}{c}{ NAA } & \multicolumn{3}{c}{ Experiment } & \\
\cline { 2 - 3 } (mg.liter ${ }^{-1}$ ) & \multicolumn{1}{c}{1} & \multicolumn{1}{c}{ Mean (\%) } \\
\hline 0.000 & $0 / 15$ & $3 / 19$ & 8 \\
0.001 & $1 / 15$ & $2 / 17$ & 9 \\
0.010 & $6 / 15$ & $16 / 36$ & 42 \\
0.100 & $3 / 15$ & $4 / 16$ & 22 \\
LSD (5\%) & & & 18 \\
CV (\%) & & & 31 \\
\hline
\end{tabular}

${ }^{2}$ Data represent the mean of two experiments. The response is significantly different among treatments. $\chi^{2}$ value is $16.7(P<0.001)$.

treatment. After 3 weeks, cultures were evaluated for the production of organogenic sectors. To resolve statistical differences between treatments, data from two independent experiments were entered into a contingency table and $x^{2}$ values were computed. Agarsolidified MS medium supplemented with one of four levels of NAA $(0.0,0.001,0.01,0.1$ $\mathrm{mg} \cdot$ liter $^{-1}$ ) was evaluated for rooting of shoots. When plantlets developed an extensive root system, they were transplanted to pots containing a planting mix and covered with clear polyethylene storage bags for hardening-off. Subsequently, the regenerated plants were potted in soil and grown in a greenhouse.

Two types of tissue were produced by the cotyledon explants, a compact green organogenic tissue and a green friable callus. The best induction medium was MS medium supplemented with $1.0 \mathrm{mg} \mathrm{BA} / \mathrm{liter} ; 80 \%$ of explants cultured on this medium produced organogenic tissue (Table 1). The difference in response between all media formulations was highly significant. The difference between 1 and $0.75 \mathrm{mg} \cdot$ liter $^{-1}$ was also highly significant $\left(x^{2}=19.1^{* *}\right)$. The least organogenic tissue was generated from explants cultured on a medium with $0.5 \mathrm{mg} \mathrm{BA} / \mathrm{liter}$ other than from the control. Only one-fourth as many explants with I-K medium produced organogenic tissue as those with $1 \mathrm{mg} \mathrm{BA} /$ liter.

Organogenic tissues could be serially propagated by subculture on MS with BA at 0.75 or $1.0 \mathrm{mg} \cdot \operatorname{liter}^{-1}$ (Fig. 1). Generally,

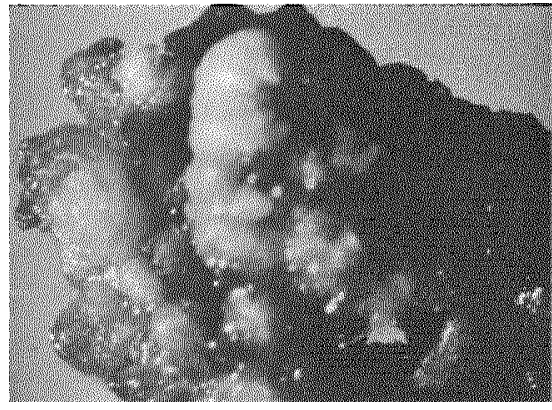

Fig. 1. Organogenic tissue derived from cotyledon explant.

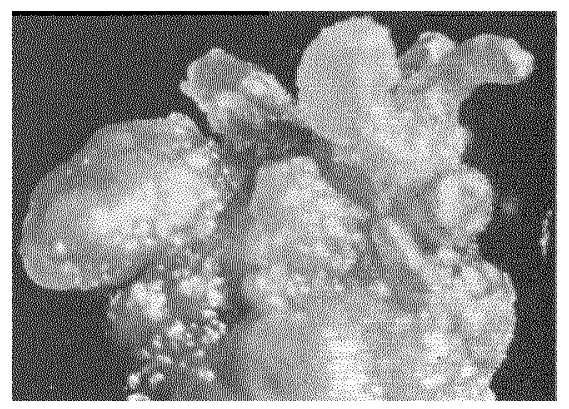

Fig. 2. Organogenic tissue with developing vegetative buds.

organogenic tissues lost morphogenic potential and produced friable callus when serially subculture on I-K medium. Shoot development was subsequently promoted by transfer of the organogenic tissues to MS with $0.05 \mathrm{mg} \mathrm{BA} /$ liter. Forty percent of the organogenic tissue then produced many shoot buds (Fig. 2). Shoots developed within 20 days of transfer to this latter medium (Fig. 3 ). Further shoot development was encouraged by transfer of organogenic tissue to Magenta boxes (Magenta Corp., Chicago) containing four sheets of sterile paper towel saturated with $\approx 20 \mathrm{ml}$ of MS liquid medium containing BA at $0.05 \mathrm{mg} \cdot$ liter $^{-1}$. Fresh medium was added to boxes every 2 weeks.

Developing shoots, $\approx 1 \mathrm{~cm}$ in length, were dissected from the mass of organogenic tissues and transferred to rooting medium. The remainder of the organogenic tissue was returned to liquid medium in Magenta boxes for further shoot development. The differences in the frequency of root development due to NAA concentration were significant. The highest rooting percentage was obtained in a medium containing $0.01 \mathrm{mg} \mathrm{NAA} / \mathrm{liter}$ (Table 2). Although medium containing no NAA was ineffective for root formation, a difference between NAA at $0,0.001$, and $0.1 \mathrm{mg} \cdot \mathrm{liter}^{-1}$ could not be resolved $\left(x^{2}=\right.$ $\left.2.63^{\mathrm{NS}}\right)$. The difference between 0.01 $\mathrm{mg} \cdot 1$ iter $^{-1}$ and all other treatments pooled was highly significant $\left(x^{2}=14.96^{* *}\right)$. The medium containing NAA at $0.1 \mathrm{mg} \cdot \mathrm{liter}^{-1}$ stimulated callus growth at the shoot bases. Rooted plants flowered and produced fruits with seed.

Organogenesis from cotyledon of $\mathrm{Cucu}$ mis melo has been reported earlier (Dirks and van Buggenum, 1989; Niedz et al., 1989).

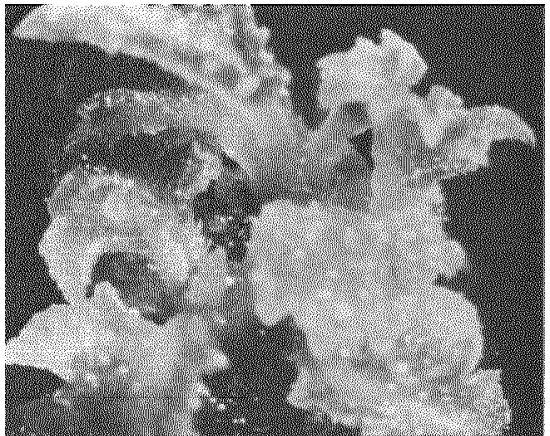

Fig. 3. Shoot formation from organogenic tissues.

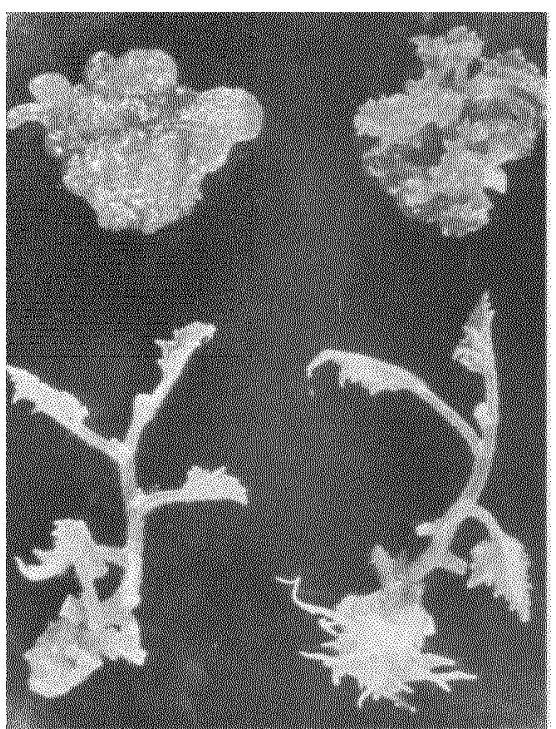

Fig.4. Regeneration stages of muskmelon from cotyledon explant. (Upper left) Initiation of organogenic tissue. (Upper right) Differentiation of organogenic tissue. (Lower left) Plantlet development. (Lower right) Regenerated muskmelon plant.

The differences between the present results and the earlier ones are the cultivar used, concentration of growth regulators, and the ability to propagate organogenic tissues. We used cotyledons of 'Topmark' and 'Perlita' as explant sources; while the others used cotyledons of 'Hale's Best Jumbo' (Niedz et al., 1989), 'Accent', 'Galia', 4215, 'Presto', and 'Viva' (Dirks and van Buggenum, 1989). We were able to induce organogenic callus tissues by culture of the explants on MS medium with $1.0 \mathrm{mg} \mathrm{BA} / \mathrm{liter}$ and shoot development could be promoted by transfer of the organogenic tissues to MS medium with 0.05 mg BA/liter. In contrast, Niedz et al. (1989) reported that $75 \%$ of the explants were induced to form organogenic callus with the use of IAA at $0.875 \mathrm{mg} \cdot$ liter $^{-1}$ and abscisic acid at $0.26 \mathrm{mg} \cdot$ liter $^{-1}$ in combination with $\mathrm{BA}$ at $1.0 \mathrm{mg}$ as inductive growth regulators. Shoot formation $(30 \%)$ was obtained by transfer of shoot buds to MS medium with BA at $0.675 \mathrm{mg} \cdot$ liter $^{-1}$. In addition, Dirks and van Buggenum (1989) obtained shoot formation directly from every cotyledon explant cultured on MS medium that contained 
BA at $1.0 \mathrm{mg} \cdot 1$ iter $^{-1}$. In the work reported here, the competence of organogenic tissue was maintained by serial propagation on MS medium with $1.0 \mathrm{mg} \mathrm{BA} / \mathrm{liter}$.

Moreno et al. (1985) maintained organogenic tissues of 'Amarillo Oro' muskmelon for 1 year using I-K medium. However, when organogenic calli of 'Topmark' were serially subculture onto I-K medium, morphogenic competency was lost and only friable tissues were produced. Such difference in morphogenic responses is likely due to genetic differences between the cultivars. The procedure reported here (Fig. 4) may be applicable to other muskmelon cultivars, as 'Perlita' and 'Topmark' responded similarly. Cotyledons have proven to be an excellent source of transformation experiments in Cucumis sativus (Chee, 1990a, 1990b). The simple regeneration method described may be useful in gene transfer using either Agrobacteria or microprojectile bombardment.

\section{Literature Cited}

Blackmon, W.J. and B.D. Reynolds. 1982. In vitro shoot regeneration of Hibiscus acetosella, musk-melon and winged bean. HortScience 17:588-589.

Chee, P.P. 1990a. Transformation of Cucumis sativus via Agrobacterium tumefaciens, p. 85-90. In: H.J.J. Nijkamp, L.H.W. Van Der Plas, and J. Van Aartrijk (eds.). Progress in plant cellular and molecular biology. Kluwere Academic, The Netherlands.

Chee, P.P. 1990b. Transformation of Cucumis sativus tissue by Agrobacterium tumefaciens and the regeneration of transformed plants. Plant Cell Rpt. 9:245-248.

Dirks, R. and M. van Buggenum. 1989. In vitro plant regeneration from leaf and cotyledon explants of Cucumis melo L. Plant cell Rpt. 7:626627.
Kathal, R., S.P. Bhatnagar, and S.S. Bhojwani. 1988. Regeneration of plants from leaf explants of Cucumis melo cv. Pusa Sharbati. Plant Cell Rpt. 7:449-451.

Moreno, V., M. Garcia-Sogo, I. Granell, B. Garcia-Sogo, and L.A. Roig. 1985. Plant regeneration from calli of melon (Cucumis melo L., cv. "Amarillo Oro"). Plant Cell Tissue Organ Culture 5:139-146.

Murashige, T. and F. Skoog. 1962. A revised medium for rapid growth and bioassays with tobacco tissue cultures. Physiol. Plant 15:473497.

Niedz, R.P., S.S. Smith, K.B. Dunbar, C.T. Stephens, and H.H. Murakish. 1989. Factors influencing shoot regeneration from cotyledonary explants of Cucumis melo. Plant Cell Tissue and Organ Culture 18:313-319.

Oridate, T. and K. Oosawa. 1986. Somatic embryogenesis and plant regeneration from suspension callus culture in melon (Cucumis melo L.) Jpn. J. Breed. 36:424-428. 